\title{
PENINGKATAN KETERAMPILAN BERPIKIR KRITIS DAN HASIL BELAJAR MELALUI PENERAPAN MODEL PROBLEM BASED LEARNING
}

\author{
Fadli A. M. Mandagi ${ }^{1}$, Marthen Paloboran ${ }^{2}$, Sudirman ${ }^{3}$ \\ ${ }^{1}$ Teknik Otomotif, Sekolah Menengah Kejuruan Negeri 1 Banggai \\ fadli.a.m.mandagi@gmail.com \\ ${ }^{2}$ Teknik Otomotif, Universitas Negeri Makassar \\ marthen.paloboran@unm.ac.id \\ ${ }^{3}$ Teknik otomotif, Sekolah Menengah Kejuruan Negeri 3 Gowa \\ sudirmanganing@yahoo.com
}

\begin{abstract}
ABSTRAK
Penelitian ini bertujuan untuk meningkatkan keterampilan berpikir kritis dan hasil belajar peserta didik SMK Negeri 1 Banggai kelas XI Teknik dan Bisnis Sepeda Motor dalam pembelajaran perawatan mekanisme katup dan kelengkapannya melalui penerapan model pembelajaran problem based learning. Penelitian ini merupakan penelitian tindakan kelas. Subjek penelitian ini adalah Peserta didik kelas XI Teknik dan Bisnis Sepeda Motor. Teknik pengambilan data dengan menggunakan metode pengamatan dan perangkat checklist serta uji kinerja. Data yang didapatkan dianalisis secara descriptive. Hasil penelitian ini menunjukkan bahwa diterapkannya model problem based learning pada kompetensi dasar perawatan mekanisme katup dan kelengkapannya, dapat meningkatkan tingkat berpikir kritis dan hasil belajar peserta didik serta mencapai tujuan pembelajaran dengan rincian sebagai berikut: (a) meningkatnya keterampilan berpikir kritis peserta didik setelah penerapan model dengan kategori sangat tinggi sebanyak 38 Peserta didik (71,69\%), kategori tinggi sebanyak 12 Peserta didik (22,64\%), kategori rendah sebanyak 3 Peserta didik $(5,66 \%)$ dan kategori sangat rendah yaitu sebanyak 0 Peserta didik $(0 \%)$; (b) penerapan pembelajaran model problem based learning dapat meningkatkan hasil belajar Peserta didik sebesar 33,97\%; dan (c) Hasil belajar Peserta didik setelah penerapan model problem based learning, peserta didik yang mencapai Standar Ketuntasan Minimum sebanyak 53 Peserta didik (100\%).
\end{abstract}

Kata Kunci: Penelitian Tindakan Kelas, Berpikir Kritis, Hasil Belajar, Problem Based Learning.

\section{IMPROVING CRITICAL THINKING SKILLS AND LEARNING OUTCOMES THROUGH THE APPLICATION OF THE PROBLEM BASED LEARNING MODEL}

\begin{abstract}
This study aims to improve critical thinking skills and learning outcomes of students of SMK Negeri 1 Banggai class XI Motorcycle Engineering and Business in learning about valve mechanism maintenance and its completeness through the application of a problem-based learning model. This research is classroom action research. The subjects of this study were students of class XI Motorcycle Engineering and Business. Data collection techniques using observation methods and checklist devices as well as performance tests. The data obtained were analyzed descriptively. The results of this study indicate that the implementation of the problem-based learning model on the basic competence of valve mechanism maintenance and its accessories can increase the level of critical thinking and student learning outcomes and achieve learning objectives with the following details: (a) increasing students' critical thinking skills after the application of the model. with a very high category of 38 students (71.69\%), high category of 12 students $(22.64 \%)$, low category of 3 students (5.66\%) and very low category of 0 students $(0 \%) ;(b)$ the application of problem-based learning model learning can improve student learning outcomes by 33.97\%; and (c) Student learning outcomes after the application of the problem-based learning model, the students who achieved the Minimum Mastery Standard were 53 students (100\%).
\end{abstract}

Keyword: Classroom Action Research, Critical Thinking, Learning Outcomes, Problem Based Learning. 


\section{PENDAHULUAN}

Partnership for 21st Century Learning (P21) mengembangkan framework pembelajaran di abad 21 yang mana peserta didik dituntut untuk mempunyai keterampilan, knowledge dan kompetensi dibidang teknologi, media informasi, skill pembelajaran dan inovasi serta keterampilan hidup dan berkarir. Framework menjelaskan bagaimana keterampilan, knowledge dan kompetensi yang harus dimiliki supaya peserta didik dapat berhasil dalam segi kehidupan serta bidang pekerjaan. Kemendikbud merumuskan bahwa paradigma pembelajaran abad 21 ini menekankan pada kemampuan peserta didik untuk mencari tahu berbagai sumber, merumuskan permasalahan, berpikir analisis dan bekerja dalam tim work serta berkolaborasi guna menyelesaikan masalah. Pembelajaran abad 21 adalahpembelajaran yang dirancang guna membekali peserta didik abad 21 yang dapat mengikuti arus teknologi. Hal ini, terutama dalam ranah pendidikan vokasional yang telah masuk berbagai kesendi kehidupan, maka sangat diharapkan peserta didik saat ini harus mampu menguasai 4 (empat) keterampilan belajar (4C), yakni salah satunya adalah critical thinking and problem solving. Abad ke-21 juga dikenal dengan masa knowledge age, semua alternatif dalam pemenuhan kebutuhan hidup dalam berbagai lini berbasis knowledge. Upaya pemenuhan kebutuhan pendidikan, pengembangan ekonomi pengembangan dan pemberdayaan masyarakat dan bidang industri pun berbasis knowledge [1].

Sekolah Menengah Kejuruan (SMK) adalah lembaga pendidikan vokasional yang diharapkan mampu menghasilkan outcome yang produktif yang memiliki kualitas Skill hebat. Bukan hanya sekadar cakap dalam knowledge namun generasi yang memiliki skill berdaya saing di dunia usaha/dunia industri. Untuk menghasilkan generasi hebat sebagai modal antisipasi revolusi industri 4.0, maka menjadi wajar kalau nanti dunia pendidikan vokasional menerapkan pembelajaran abad 21. Ini didukung guna mengimbangi timbulnya karakter peserta didik yang sampai saat ini cenderung aktif dan kreatif. Pembelajaran abad 21 adalah pembelajaran yang bercirikan pembelajaran skill, keterampilan, dan literasi. Pembelajaran skill adalah kegiatan pembelajaran yang di dalamnya ditandai dengan adanya kerjasama, komunikasi, dan berpikir kritis serta kreatif. Sehingga diharapkan menghasilkan lulusan SMK dari generasi produktif yang memiliki kualitas dan skill hebat.
SMK Negeri 1 Banggai merupakan salah satu lembaga pendidikan kejuruan menengah dengan bidang keahlian teknologi rekayasa informasi dan komunikasi dengan salah satu kompetensi keahliannya yaitu Teknik Dan Bisnis Sepeda Motor (TBSM) yang sampai sekarang peserta didiknya masih kesusahan dalam pelaksanaan praktik pembelajaran perawatan mekanisme katup dan kelengkapannya. Hasil refleksi pelaksanaan prakerin di bengkel terdapat masalah berupa peserta didik masih ragu-ragu dalam menyelesaikan pekerjaan yang diberikan. Hal ini terbukti saat peserta didik diberikan job merawat mekanisme katup dan kelengkapannya mereka kesulitan dalam menganalisis gangguan mekanisme katup dan kelengkapannya. Menurut [2] "Traditionally, direct preparation for work was the main goal of vocational education". Pendidikan kejuruan memiliki tujuan utama yaitu menyiapkan anak didiknya guna memasuki lapangan kerja. Seharusnya pelaksanaan pembelajaran di SMK, memperbanyak pembelajaran praktik guna membekali keterampilan pada peserta didiknya.

Hasil obeservasi dilapangan saat proses belajar praktik yang dilaksanakan di workshop sekolah terlihat belum sesuai yang diharapkan. Hanya beberapa peserta didik yang dominan dan aktif serta sebagian besar peserta didik cenderung pasif, sehingga pembelajaran terkesan belum maksimal. Selain itu dapat dilihat dari hasil tes uji kinerja peserta didik menunjukkan bahwa kelas XI TBSM A berjumlah 16 peserta didik $(61,53 \%)$ dari 26 peserta didik dan kelas XI TBSM B berjumlah 19 peserta didik (70,37\%) dari 27 peserta didik belum kompeten, sehingga peneliti harus melakukan pembelajaran remidial. Permasalahan ini menggambarkan bahwa peserta didik tengah kesulitan dalam menyelesaikan job yang diberikan. Berdasarkan temuan diatas menunjukkan bahwa hasil belajar peserta didik masih di bawah Standar Ketuntasan Minimum (SKM). Proses perawatan mekanisme katup dan kelengkapannya mengimplikasikan skill analisis dan berdasarkan hasil analisis mampu membuat kesimpulan yang tepat. Keterampilan perawatan mekanisme katup dan kelengkapannya termasuk kategori berpikir kritis. Menurut [3] Pembelajaran model Problem Based Learning (PBL) memusatkan belajar menjadi proses yang melibatkan solusi dan berpikir kritis dalam kondisi yang sesungguhnya.

Model pembelajaran PBL yaitu sebuah ancangan pembelajaran yang menyuguhkan problem rill sehingga membangkitkan peserta didik dalam belajar. Di dalam sebuah kelas yang menyajikan model pembelajaran PBL, peserta didik belajar dalam kelompoknya guna mengatasi masalah real world [4]. 
Keterampilan berpikir kritis dapat dibangun dengan peneliti memberikan pengalaman belajar berbasis masalah. Desain pembelajaran masalah yang mengaikan keterampilan berpikir peserta didik dan analisis berdasar pada masalah yang rill. Model pembelajaran berbasis masalah yang dimaksud yakni model Problem Based Learning (PBL). [5] mengatakan:

The goals of problem based learning are to help students develop flexible knowledge that can be applied in many situations, in contrast to inert knowledge. ....

Other goals of problem based learning are to enhance intrinsic motivation and skills in problem solving, collaboration, and self directed lifelong learning.

Pembelajaran berbasis masalah (PBL) bertujuan untuk mendukung peserta didik menumbuhkan pengetahuan yang luwes yang akan diaplikasikan dalam kondisi tertentu, beda dengan menyisipkan knowledge. Selain itu PBL, bertujuan untuk menambah motivasi intrinsik dan skill dalam memecahkan masalah, kerjasama, dan belajar mandiri sepanjang hayat. Menurut [6] seseorang dianggap berpikir kritis dengan baik jika: (a) Mengajukan pertanyaan sesuai topic permasalahan; (b) mengolah dan membandingkan informasi yang sesuai; (c) menyimpulkan dan memberikan solusi menggunakan daya penalaran; (d) Berpikir terbuka; (e) komunikatif dalam memberikan solusi. Menurut [7] bahwa keterampilan utama yang harus dimiliki peserta didik abad 21 adalah keterampilan berpikir kritis karena berkaitan dengan proses pemecahan masalah yang terjadi dalam kehidupan sehari-hari, pekerjaan, dan lain-lain. Jadi, ketika seseorang berpikir kritis maka dapat memutuskan dengan tepat apa yang seharusnya dipercayai dan yang harus dilakukan. Menurut [8] mengemukakan bahwa tahapan dalam model pembelajaran PBL terdapat 5 sintak yakni (a) orientasi peserta didik dengan masalah; (b) mengelompokan peserta didik guna penyelidikan; (c) memfasilitasi penyelidikan mandiri dan/atau kelompok; (d) mengelaborasi dan menampilkan hasil; (e) mengkaji dan menilai proses.

Hasil penelitian yang dilakukan [9] mengemukakan bahwa penerapan model pembelajaran PBL dapat meningkat kemampuan berpikir kritis peserta didik meningkat 87,50\%, kegiatan peneliti menunjukkan kenaikan 91,9\%, kegiatan peserta didik meningkat sebesar 84,57\%, dan umpan balik peserta didik sebesar 89,06\% Selanjutnya hasil penelitian [10] menyatakan bahwa penerapan model pembelajaran PBL dapat peningkatan kemampuan berpikir kritis dalam setiap kategori dan peningkatan hasil belajar sebesar $38 \%$. [11] hasil penelitiannya menunjukkan bahwa (a) hasil belajar siswa yang menggunakan model pembelajaran berbasis masalah secara signifikan lebih tinggi; (b) hasil belajar siswa yang memiliki kemampuan analisis tinggi secara signifikan lebih tinggi; dan (c) terdapat interaksi antara penggunaan model pembelajaran berbasis masalah dan model pembelajaran langsung terhadap hasil belajar pada kompetensi dasar mata pelajaran sistem rem di SMKN 2 Kupang. Menurut [12] penerapan model pembelajaran PBL dapat meningkatkan hasil belajar. Melihat karakteristik dari model pembelajaran PBL sangat sesuai jika diterapkan pada pembelajaran kompetensi dasar perawatan mekanisme katup dan kelengkapannya di kelas XI TBSM SMKN 1 Banggai.

Mendasari latar belakang diatas, penelitian ini bertujuan untuk: (a) meningkatkan keterampilan berpikir kritis peserta didik pada kompetensi dasar perawatan mekanisme katup dan kelengkapannya melalui penerapan model pembelajaran PBL; (b) meningkatkan hasil belajar peserta didik pada kompetensi dasar perawatan mekanisme katup dan kelengkapannya melalui penerapan model pembelajaran PBL; (c) mengetahui keterampilan berpikir kritis peserta didik pada kompetensi dasar perawatan mekanisme katup dan kelengkapannya setelah penerapan model pembelajaran PBL; (d) mengetahui hasil belajar peserta didik pada kompetensi dasar perawatan mekanisme katup dan kelengkapannya setelah penerapan model pembelajaran PBL.

\section{METODE PENELITIAN}

Metode penelitian yang digunakan merupakan Penelitian Tindakan Kelas (PTK) yang terdiri dari 4 tahapan yaitu perencanaan, pelaksanaan, pengamatan, dan refleksi. Dengan melibatkan seorang kolaborator yang mendapingi peneliti melaksanakan proses pembelajaran PBL dan mengamati peserta didik selama pembelajaran. Pelaksanaan Penelitian pada bulan Juli sampai Agustus 2021. Kondisi ini disesuaikan dengan kompetensi dasar perawatan mekanisme katup dan kelengkapannya pada semester ganjil tahun pelajaran 2021/2022. Bertempat di SMK Negeri 1 Banggai di Jalan Bubung Batu No. 01 Desa Lampa Kecamatan Banggai Kabupaten Banggai Laut Provinsi Sulawesi Tengah. Subjek penelitian adalah peserta didik kelas XI TBSM SMK Negeri 1 Banggai sebanyak 53 orang. Data yang diperoleh berbentuk data kuantitatif hasil pengamatan aktivitas peneliti dan peserta didik saat proses pembelajaran PBL pada 
kompetensi dasar perawatan mekanisme katup dan kelengkapannya. Teknik pengambilan data dengan metode pengamatan menggunakan perangkat checklist $(\sqrt{ })$ dan uji kinerja. Teknik analisis data mengunakan analisis descriptive.

\section{HASIL DAN PEMBAHASAN}

Penelitian Tindakan Kelas (PTK) ini menggunakan model Kemmis yang tahapannya terdiri dari perencanaan, pelaksanaan, pengamatan dan refleksi. Pada tahap perencanaan, peneliti merencanakan aktivitas yang dilakukan guna menaikan skill berpikir kritis dan hasil belajar peserta didik melalui penerapan model pembelajaran PBL. Perencanaan aktivitas yakni persiapan jaduwal, perangkat model pembelajaran PBL, peralatan dan bahan praktik, media pembelajaran, Lembar Kerja Peserta Didik (LKPD) dan instrumen penelitian. Selanjutnya peneliti mengimplementasikan pembelajaran yang direncanakan. Sedangkan kolaborator mengamati dan mengisi perangkat ceklist selama aktivitas pembelajaran perawatan mekanisme katup dan kelengkapannya berlangsung. 5 (lima) sintak Model pembelajaran PBL dilaksanakan peneliti dan peserta didik yaitu: (a) Sintak 1 peneliti memberikan gambaran permasalahan pada peserta didik: Peneliti menyampaikan tujuan pembelajaran, menjelaskan berbagai kebutuhan sarana belajar, dan memberi motivasi pada peserta didik; (b) Sintak 2 peneliti mengelompokan peserta didik: peneliti memfasilitasi peserta didik dalam mendefinisikan dan mngelompokan tugas belajar; (c) Sintak 3 peneliti memfasilitasi penyelidikan mandiri dan/atau kelompok: peneliti mendukung peserta didik mencari informasi, melaksanakan percobaan, dan mencari definisi serta solusi; (d) Sintak 4 pengembangan dan pemaparan hasil: peneliti memfasilitasi peserta didik pada perencanaan dan penyiapan portopolio untuk menyampaikan kepada teman dan/atau kelompok yang lain; (e) Sintak 5 analisis dan evaluasi proses: peneliti memfasilitasi peserta didik dalam melaksanakan gambaran terhadap hasil penyelidikan.

Peneliti bertindak sebagai pengajar dibantu observator yang bertugas mengamati secara langsung pada proses pembelajaran berlangsung yang bertujuan untuk mengetahui ada dan/atau tidaknya perubahan yang terjadi dalam pelaksanaan tindakan yang sedang dilaksanakan. Refleksi data berupa hasil pengamatan dan uji kinerja. Hasil refleksi menjadi dasar untuk menentukan pelaksanaan tahapan pada siklus berikutnya.

\section{HASIL}

Prosedur dari penelitian yang dilakukan menggunakan prosedur PTK yang terdiri atas tahapan perencanaan, implementasi, pengamatan, dan refleksi. Setiap tahapan aktivitas, peneliti diamati oleh kolaborator. Kolaborator bertugas membantu peneliti mengamati kegiatan di dalam kelas. Pelaksanaan PTK ini yang dilakukan terdiri 2 (dua) siklus, yang pelaksanaannya mulai dari tanggal 1 Juli 2021 sampai dengan 14 Agustus 2021. Pelaksanaan pembelajaran dengan model pembelajaran PBL, peserta didik dibagi menjadi 12 kelompok dan masing-masing kelompok terdiri dari 4 peserta didik dan 1 kelompok terdiri 5 peserta didik, dengan kemampuan knowledge dan skill beda. Setiap kelompok menghadapi 1 (satu) unit sepeda motor dengan problem kerusakan yang akan diselesaikan oleh peserta didik pada setiap tahapan model pembelajaran PBL. Hasil pekerjaan perawatan mekanisme katup dan kelengkapannya disajikan dalam lembar LKPD dan dipresentasikan didepan kelas.

\section{Siklus I}

\section{Kegiatan Peneliti dalam Model Pembelajaran PBL}

Data kegiatan peneliti yang diperoleh pada pengamatan selama pembelajaran berlangsung. Poin perolehan kegiatan peneliti yaitu sebesar 16 poin dari 16 poin. Hal ini menggambarkan kegiatan peneliti pada penerapan Model pembelajaran PBL sudah optimal.

\section{Kegiatan Peserta Didik dalam Model pembelajaran PBL}

Poin perolehan kegiatan peserta didik 188 dari 290 poin. Prosentase poin kegiatan peserta didik pada pelaksanaan model pembelajaran PBL yakni sebesar $64,82 \%$. Hal ini menggambarkan Prosentase kegiatan peserta didik pada pelaksanaan model pembelajaran PBL masih minim. Poin yang diperoleh pada setiap aspek belum mencapai standar, sehingga dapat dikatakan bahwa pembelajaran belum berjalan sesuai dengan yang diharapkan. Analisis kegiatan peserta didik dalam model pembelajaran PBL pada kategori sangat tinggi sebesar 60,4\% (32 peserta didik), kategori tinggi $15, \%$ (8 peserta didik), kategori rendah $11,32 \%$ (6 peserta didik) dan kategori sangat rendah 13,2\% (7 peserta didik). Sehingga disimpulkan peserta didik yang mengikuti model pembelajaran PBL dengan kategori baik dan kategori tinggi yaitu 40 peserta didik $(75,4 \%)$. Hasil ini menggambarkan pelaksanaan model pembelajaran PBL belum sesuai dengan yang diharapkan maka diperlukan pengembangan lebih lanjut. 


\section{Keterampilan Berpikir Kritis Peserta Didik}

Hasil pengamatan keterampilan berpikir kritis peserta didik pada siklus I didapatkan 478 poin dari 725 poin, sehingga dapat dipresentasekan sebesar 65,93\%. Data ini dapat menggambarkan pencapaian poin aspek keterampilan berpikir kritis tidak memenuhi standar $80 \%$ yang telah ditentukan. Keterampilan berpikir kritis peserta didik dikelompokan kedalam 4 kelompok yakni sangat tinggi, tinggi, rendah dan sangat rendah. Data menunjukkan bahwa keterampilan berpikir kritis peserta didik pada kelompok sangat tinggi yaitu 23 peserta didik $(43,39 \%)$, kategori tinggi 10 peserta didik $(18,86 \%)$, kategori rendah 20 peserta didik $(37 \%)$ dan kategori sangat rendah 0 peserta didik $(0 \%)$. Tolok ukur keberhasilan yang ditetapkan pada penelitian ini sebesar $80 \%$ atau 42 peserta didik dalam kelompok tinggi. Berdasar data di atas, peserta didik yang masuk dalam kelompok keterampilan berpikir kritis sangat tinggi dan tinggi yakni 33 peserta didik atau 62,26\%, maka ditarik kesimpulan saat pelaksanaan siklus I keterampilan berpikir kritis belum terlaksana. Sehingga keterampilan berpikir kritis perlu ditingkatkan lagi secara presfektif.

\section{Hasil belajar Peserta Didik}

Hasil belajar peserta didik yang diambil dari hasil uji kinerja. Dimensi yang dievaluasi adalah persiapan kerja, sikap kerja, proses kerja, dan hasil kerja, serta waktu kerja. Dari lembar hasil penilaian didapat skor tertinggi 90, skor terendah 70, dengan rata-rata skor 75. Dari data di atas banyaknya peserta didik yang mencapai skor standar SKM sebanyak 35 peserta didik $(66,03 \%)$ Peserta didik dan yang belum mencapai standar SKM sebanyak 18 peserta didik $(33,96 \%)$. Maka model pembelajaran PBL dapat dinyatakan berhasil jika dimensi kelulusan mencapai $80 \%$ peserta didik yang mendapatkan skor standar atau di atas SKM. Data di atas menggambarkan peserta didik yang tuntas SKM $(66,03 \%)$ sehingga masih diperlukan adanya perbaikan dan pengembangan pembelajaran pada siklus ke II.

\section{Siklus II}

\section{Kegiatan peneliti dalam Model pembelajaran PBL}

Kegiatan pada siklus II menunjukkan aktivitas pelaksanaan model pembelajaran PBL. Poin yang didapatkan pada siklus II ini sudah maksimal yakni 16. Pada siklus II, dilakukan seluruh sintak-sintak pada model pembelajaran PBL. Hal ini menunjukkan kegiatan peneliti pada model pembelajaran PBL sudah maksimal.

\section{Kegiatan Peserta Didik dalam Model pembelajaran PBL Siklus II}

Skor kegiatan peserta didik pada model pembelajaran PBL yakni 263 poin dari 290 poin. Prosentase poin kegiatan peserta didik pada pelaksanaan model pembelajaran PBL yakni 90,69\%. Sehingga prosentase ini menunjukkan kegiatan peserta didik pada pelaksanaan model pembelajaran PBL mengalami kenaikan dibandingkan pada siklus I. Capaian poin pada setiap peserta didik menunjukkan kegiatan peserta didik dalam model pembelajaran PBL pada kategori sangat tinggi sebanyak 48 peserta didik $(90,56 \%)$ dan kategori tinggi sebanyak 5 peserta didik $(9,43 \%)$. Dalam pelaksanaan pembelajaran pada siklus II ini, tidak terdapat peserta didik yang masuk pada kelompok rendah dan sangat rendah.

\section{Keterampilan berpikir kritis Peserta Didik Siklus II}

Pada pelaksanaan pembelajaran siklus II, poin keterampilan berpikir kritis menunjukan peningkatan. Data poin yang perolehan untuk keterampilan berpikir kritis yakni 612 poin dari 725 poin, jika diprosentasekan keterampilan berpikir kritis peserta didik sebesar $84,41 \%$. Data menunjukkan bahwa Keterampilan berpikir kritis peserta didik kategori sangat tinggi sebanyak 38 peserta didik $(71,69 \%)$, kategori tinggi sebanyak peserta didik 12 (22,64\%), kategori rendah 3 peserta didik $(5,66)$, kategori sangat rendah 0 peserta didik $(0 \%)$. Poin peserta didik yang mencapai keterampilan berpikir kritis kelompok tinggi sebanyak 50 peserta didik $(94,34 \%)$. Data ini menggambarkan pencapaian poin dimensi keterampilan berpikir kritis sudah mencukipi kriteria $80 \%$.

\section{Hasil Belajar Peserta Didik pada Siklus II}

Perolehan skor peserta didik yang tertinggi adalah 98 , dan skor terendah 78 , serta skor rata-rata 88. Data di atas jumlah peserta didik yang tuntas SKM yaitu sebanyak 53 peserta didik (100\%). Dalam pembelajaran dengan model pembelajaran PBL dikatakan berhasil jika aspek keberhasilan tuntas SKM tercapai $80 \%$ peserta didik. Data tersebut menunjukkan bahwa dimensi hasil belajar peserta didik tercapai.

\section{PEMBAHASAN}

\section{Ketercapaian Penerapan Model Pembelajaran $P B L$ pada Kompetensi Dasar Perawatan Mekanisme Katup dan Kelengkapannya}

Tercapainya model pembelajaran PBL pada kompetensi dasar perawatan mekanisme katup dan kelengkapannya selama pelaksanaan PTK ini berlangsung sesuai rencana. Pelaksanaan PTK ini dapat menggambarkan peningkatan keterampilan berpikir kritis dan hasil belajar peserta didik melalui 
model pembelajaran PBL yang berjalan sesuai yang direncanakan dengan berbagai perbaikan dan pengembangan dalam setiap siklus serta guna menggapai tujuan pembelajaran. Penerapan model pembelajaran PBL ini, dilakukan 2 (dua) siklus yang mana dalam tiap siklus terdiri dari 5 sintak model pembelajaran PBL. Pembelajaran diawali dengan peneliti menjelaskan tujuan pembelajaran, menyampaikan kebutuhan sarana dan kegiatan yang dilakukan peneliti beserta peserta didik. Peneliti membagi peserta didik menjadi 12 kelompok. Setiap kelompok diberikan sepeda motor dengan jenis kerusakan yang beragam. Setiap kelompok wajib menentukan sendiri job terkait bagaimana cara menyelesaikan perawatan mekanisme katup dan kelengkapannya dan menentukan peralatan dan bahan yang dibutuhkan. Tugas peneliti dalam PTK ini adalah sebagai fasilitator yang dibantu seorang observer.

Peserta didik belajar dalam lingkungan kelompoknya melaksanakan perawatan mekanisme katup dan kelengkapannya. Setiap kelompok melaksanakan penyelidikan terhadap kerusakan mekanisme katup dan kelengkapannya diawali dengan mengenali kemungkinan gangguan, menafsirkan kemungkinan gangguan yang tepat, merumuskan tahapan troubleshooting dan melakukan servis dengan memperhatikan Standar Operasional Prosedur (SOP). Pada bagian ini peserta didik mempelajari troubleshooting kerusakan mekanisme katup dan kelengkapannya, penanganan gejala kerusakan mekanisme katup dan kelengkapannya dan langkah perbaikan yang tepat. Peserta didik menentukan sendiri komponen sesuai dengan spesifikasi mekanisme katup dan kelengkapannya. Perawatan dan perbaikan yang dilakukan antara kelompok tidak sama persis karena permasalahan kerusakan mekanisme katup dan kelengkapannya yang diberikan adalah sedang rusak (setelah dipakai praktik peserta didik kelas lain). Peserta didik mampu memanfaatkan Buku Panduang Reparasi (BPR), Buku Pegangan Siswa, modul, internet, dan sumber lain sesuai jenis sepeda motor yang dikerjakan. Sehingga peserta didik mendapat hal baru yang secara langsung dilakukan sendiri. Disetiap akhir pembelajaran setiap kelompok memaparkan hasil kinerja perawatan mekanisme katup dan kelengkapannya. Pada tahapan ini kelompok peserta didik yang lain menanggapi untuk pengembangan knowledge yang baru yang tidak di dapatkan dari hasil pekerjaannya.

Pelaksanaan siklus I terdapat kelemahan pada tahap kegiatan peserta didik belum mencapai tahap keberhasilan. Dimensi yang paling rendah ketercapaiannya adalah pada kegiatan mempresentasikan hasil perawatan. Peserta didik masih belum berani mengemukakan pendapat dan hasil pemikiran di depan kelompok lain. Pada kegiatan membuat kesimpulan, keterlibatan peserta didik masih sangat kurang, peserta didik masih mengandalkan anggota kelompok lain bahkan terlihat cenderung diam dan pasif. terkait dengan keaktifan peserta didik dalam menggali sumber belajar untuk mencari solusi permasalahan. Peserta didik lebih banyak menunggu penjelasan peneliti ketika kesusahan dalam menelaah dan menafsirkan gangguan mekanisme katup dan kelengkapannya. Sementara itu peneliti telah menyiapkan fasilitas guna mencari informasi sebagai sumber belajar jika peserta didik kesulitan. Keterlibatan peserta didik dalam eksperimen juga belum terpenuhi. Masih ada peserta didik yang diam dan pasif serta masih ada peserta didik yang mendominasi pada saat melakukan perawatan mekanisme katup dan kelengkapannya. Skor kegiatan peserta didik kategori sangat tinggi 32 peserta didik $(60,4 \%)$, kategori tinggi 8 peserta didik $(15 \%)$, kategori rendah 6 peserta didik $(11,32 \%)$ dan kategori sangat rendah 7 peserta didik $(13,2 \%)$. Hal tersebut menggambarkan belum sepenuhnya peserta didik melibatkan diri secara optimal pada proses pembelajaran. Jadi hasil siklus I menggambarkan pembelajaran pada model pembelajaran PBL belum berjalan sesuai yang diharapkan peneliti meskipun hasil pengamatan kegiatan peneliti pada penerapan setiap tahapan model pembelajaran PBL telah optimal. Olehnya itu pada siklus II peneliti memperbaiki dan mengembangkan sebagai pebaikan siklus I.

Pada siklus II dilaksanakan 3 (tiga) pertemuan tatap muka. Diharapkan agar pembelajaran lebih optimal, peneliti menayangkan tujuan model pembelajaran PBL, kegiatan yang dilaksanakan oleh peneliti bersama peserta didik. Guna meminimalisir peserta didik yang tidak aktif, maka peneliti mengigatkan pada setiap penanggung jawab kelompok agar mendorong anggotanya pada tiap bagian pembelajaran. Guna membangkitkan peserta didik yang masih diam pada pembelajaran dan pemaparan hasil, maka peneliti mengarahkan peserta didik pada setiap kelompok untuk menjadi pemapar utama pada pemaparan selanjutnya hal ini bertujuan agar semua peserta didik turut berperan dalam penyajian hasil percobaan perawatan dan semua peserta didik mendapat giliran guna mengekspos knowledge yang didapatkan selama pembelajaran.

Pelaksanaan pembelajaran pada siklus II menggambarkan hasil dengan peningkatan yang cukup baik. Kegiatan peserta didik sebelumnya belum maksimal tapi pada siklus II sudah mengalami 
peningkatan yang siknifikan. Ketercapaian model pembelajaran PBL dalam siklus II ini diperoleh poin 263 dari 290 poin, dengan prosentase $90,69 \%$. Perolehan poin pada setiap peserta didik dalam pelaksanaan model pembelajaran PBL mengalami peningkatan yang baik. Pada akhir pelaksanaan siklus II kegiatan peserta didik sudah berada pada kelompok tinggi. Berdasar hal tersebut maka diakhir siklus II, semua peserta didik telah melakukan PBL dengan maksimal. Hal tersebut menggambarkan pada perolehan poin sebanyak 53 peserta didik peserta didik masuk dikelompok tinggi.

Keterampilan Berpikir Kritis Peserta Didik Setelah pelaksanaan Model Pembelajaran $P B L$

Keterampilan berpikir kritis pada PTK ini adalah keterampilan menggunakan dimensi berpikir yang terdiri (a) masalah yang jelas, tepat dan teliti tentang gangguan kerusakan mekanisme katup dan kelengkapannya; (b) mengakumulasi, menganalisis, mengevaluasi dan mengelolah informasi yang tepat serta bermutu; (c) berpikir analogi; (d) membuat kesimpulan yang tepat, matang dan saksama; (e) berpikir terbuka; (f) memaparkan gagasan, jalan keluar dan masukan. Aspek di atas berkaitan akan proses yang dipelajari pada kompetensi dasar perawatan mekanisme katup dan kelengkapannya. Hal ini sejalan yang dikemukakan [13] dalam penelitiannya bahwa kemampuan berpikir kritis dapat berkembang, berupa kemampuan mengidentifikasi, menganalisis, memecahkan masalah, berpikir logis dan membuat keputusan dengan tepat serta dapat menarik kesimpulan.

Pelaksanaan model pembelajaran PBL guna meningkatkan tingkat berpikir kritis peserta didik pada penelitian siklus I data menggambarkan yakni beberapa aspek perolehan poin masih minim. Pencapaian aspek masalah jelas, tepat dan teliti terhadap masalah perawatan mekanisme katup dan kelengkapannya. Tolok ukur keberhasilan yang ditetapkan pada penelitian ini yaitu $80 \%$ (43 peserta didik) pada kelompok tinggi. Sehingga didapatkan bahwa pada siklus I pada kriteria keberhasilan keterampilan berpikir kritis belum tercapai secara maksimal.

Keterampilan berpikir kritis yang dipakai pada kompetensi dasar perawatan mekanisme katup dan kelengkapannya seharusnya mendorong peserta didik dalam mencari gangguan pada perawatan mekanisme katup dan kelengkapannya. Agar peserta didik mampu merumuskan solusi perawatan dan memberikan kesimpulan maka seharusnya diawali dengan mengenali melalui mengajukan pertanyaan yang tepat seperti: bagaimanakah langkah-langkah perawatan mekanisme katup dan kelengkapannya?; Apakah terdapat bunyi aneh pada mekanisme katup dan kelengkapannya saat sepeda motor hidup?; dan pertanyaan yang menjurus dalam penyelidikan. Berawal pada pertanyaan yang diajukan akan menjadi penunjuk pada peserta didik yang akan melakukan tahap identifikasi selanjutnya. Hasil pelaksanaan pengamatan menggambarkan bahwa untuk memulai percobaan perawatan mekanisme katup dan kelengkapannya, peserta didik masih malu melemparkan pertanyaan yang mendalam dan belum mampu melakukan identifikasi mendalam. Pada dimensi mengumpulkan, penyelidikan, penilaian dan pengolahan informasi yang sesuai serta bernilai, peserta didik belum mampu menilai sesuai informasi gejala gangguan mekanisme katup dan kelengkapannya yang timbul disebabkan karena kesalahan dari memulai proses penyelidikan sehingga data yang didapat belum sesuai. Yang tidak boleh dilupakan pada dimensi keterampilan berpikir kritis yakni peserta didik dapat memaparkan hasil gagasannya, penyelesaian gangguan mekanisme katup dan kelengkapannya yang diterima. Pada dimensi ini, pencapaian poin masih terlalu rendah. Peserta didik belum berani memaparkan hasil gagasannya di depan kelompok lain, karena kwatir melakukan kesalahan. Simpulan siklus I pada dimensi keterampilan berpikir kritis peserta didik tergolong masih rendah, dilihat dari poin total pencapaiannya sebesar $62,26 \%$. Berdasar hasil ini pada pelaksanaan model pembelajaran PBL harus dilaksanakan perbaikan dalam melaksanakan siklus II. Pada siklus II peneliti menitik beratkan pada peningkatan ketercapaian dimensi di atas tetapi tetap meningkatkan aspek yang telah dicapai.

Pada siklus II, peneliti dan kolaborator bertugas sebagai fasilitator. Peneliti mendorong peserta didik yang kesulitan dengan mengajukan permasalahan, hal ini bisa memacu proses identifikasi. Peneliti memberikan sample bagaimana menghubungkan gagasan yang logis dengan adanya gangguan perawatan mekanisme katup dan kelengkapannya dengan kelanjutan penyelidikan lain. Hal ini dapat mendorong peserta didik agar memfokuskan keterampilan logis gangguan kerusakan yang ada. Jika terdapat peserta didik yang kesulitan mengajukan pertanyaan atau mengalami kesusahan dalam belajar, maka peneliti mengarahkan dan mendampingi peserta didik agar mencari sumber referensi yang tepat. Selanjutnya untuk memancing peserta didik terlibat dalam mempresesntasikan hasil gagasannya, pada saat pemaparan berlangsung, peneliti akan bertanya pada peserta didik yang diam dan pasif, supaya mampu mengkomunikasikan dan mempresentasikan 
hasil pemikirannya terhadap eksperimen perawatan mekanisme katup dan kelengkapannya yang telah dilakukan sebelumnya.

Hasil siklus II dalam dimensi keterampilan berpikir kritis menggambarkan adanya peningkatan. Pencapaian poin pada siklus II adalah 612 dari 725 poin, jika diprosentasekan keterampilan berpikir kritis peserta didik didapatkan $84,41 \%$. Berdasarkan perolehan poin diatas menunjukkan bahwa kriteria keberhasilan telah tercapai. Masing-masing dimensi keterampilan berpikir kritis mengalami peningkatan. Sehingga diakhir siklus II dimensi keterampilan berpikir kritis mengalami kenaikan. Keterampilan berpikir kritis peserta didik dimensi sangat tinggi 38 peserta didik $(71,69 \%)$, dimensi tinggi 12 peserta didik $(22,64 \%)$, dimensi rendah 3 peserta didik $(5,66)$, dimensi sangat rendah 0 peserta didik $(0 \%)$. Kategori peserta didik yang mencapai keterampilan berpikir kritis tinggi 50 peserta didik $(94,34 \%)$ hal ini dapat dikatakan kriteria keberhasilan siklus II sudah terpenuhi.

Meningkatnya jumlah peserta didik yang termasuk pada kelompok tinggi disebabkan karena peserta didik sudah mampu menerapkan tahapan berpikir kritis melalui penerapan model pembelajaran PBL. Permasalahan yang diberikan pada model pembelajaran PBL, peserta didik terlibat dalam penyelesaian permasalahan dalam menggunakan keterampilan berpikir kritis. [14] bahwa penerapan model pembelajaran PBL dalam pembelajaran dapat meningkatkan keterampilan berpikir kritis peserta didik, hal tersebut ditunjukkan dengan meningkatnya keterampilan berpikir kritis pada awal kondisi, siklus 1, dan siklus 2. Waktu kondisi awal sebelum dilaknakana model pembelajaran PBL keterampilan berpikir kritis siswa sbesar $43 \%$, untuk siklus 1 dan setelah mendapatkan penerapan model pembelajaran PBL meningkat menjadi $76 \%$, serta pada siklus 2 meningkat $97 \%$. Hal ini sejalan dengan hasil penelitan yang dikemukakan [15] bahwa aktivitas pembelajaran berorientasi masalah dapat membantu peserta didik mengembangkan kemampuan pemecahan masalah, berpikir kritis, dan juga keterampilan intelektualnya.

\section{Hasil Belajar Peserta Didik Setelah Penerapan Model pembelajaran PBL}

Berhasil dan tidaknya sebuah proses pembelajaran dengan menggunakan model pembelajaran PBL pada peserta didik dapat dilihar dari hasil tes. Pada akhir penerapan model pembelajaran PBL, peneliti melaksanakan tes uji kinerja guna mengetahui bagaimana kompetensi dasar pembelajaran dapat diserap peserta didik.
Tes uji kinerja dilaksanakan 2 (dua) kali yakni pada akhir siklus I dan diakhir siklus II. Tes uji kinerja adalah tes guna mengetahui kinerja peserta didik dalam melakukan langkah-langkah pada perawatan mekanisme katup dan kelengkapannya. Uji dilaksanakan secara individu, maka peneliti dapat mengetahui mana peserta didik yang belum kompeten pada kompetensi dasar tersebut, dan dapat menemukan secara detail dimensi apa saja yang masih rendah.

Penilaian siklus I menggambarkan bahwa skor tertinggi 90, skor terendah 70, rata-rata skor 75 . Banyaknya Jumlah peserta didik yang tuntas SKM yaitu $35(66,03 \%)$ dan yang belum tuntas SKM 18 $(33,96 \%)$. Dilihat dari rekapitulasi skor untuk tiap aspek uji kinerja, masih terdapat peserta didik yang memperoleh skor zero (0) pada dimensi sikap, hasil kinerja, dan waktu. Hal ini disebabkan adanya peserta didik pada saat tes uji kinerja tidak memperhatikan momen pengencangan baut sehingga pada saat ujicoba terdapat komponen yang rusak karena dol (aus). Kekeliruan tersebut yang menyebabkan sepeda motor tidak selesai diperbaiki disebkan habis waktu, maka dimensi tes hasil kinerja dan waktu mendapat skor zero (0).

Dengan mempertimbangkan hasil tes uji kinerja pada siklus I, peneliti memberikan pengarahan pada peserta didik bagaimana pentingnya menerapkan keselamatan, kesehatan kerja (K3) serta pengguanaan Buku Panduan Reparasi (BPR) pada saat praktik demi keamanan dan keselamatan dan akesehatan diri sendiri serta peralatan yang digunakan. Supaya peserta didik dapat menyelesaikan perbaikan gangguan mekanisme katup dan kelengkapannya agar memanfaatkan waktu yang diberikan, peneliti memberikan memotivasi untuk menggunakan keterampilan berpikir kritis supaya lebih fokus menyelesaikan perbaikan gangguan sesuai dengan hasil temuan yang tepat. Hasil penskoran menggambarkan adanya peningkatan skor pada dimensi sebelumnya yang masih kurang disiklus I. Dari data rekapitulasi siklus II diperoleh skor tertinggi adalah 98, skor terendah 78, rata-rata skor 88 . Banyaknya peserta didik yang mencapai skor standar SKM adalah 53 peserta didik. Menurut [16] penguasaan peserta didik meningkat dari kategori rendah menjadi tinggi disamping itu peserta didik juga lebih disiplin aktif dan bertanggung jawab dalam mengikuti kegiaan pembelajaran.

Peningkatan hasil belajar peserta didik pada siklus II terkait dengan semakin meningkatnya penguasaan peserta didik pada langkah-langkah perawatan mekanisme katup dan kelengkapannya dengan memaksimalkan keterampilan berpikir kritis pada penerapan model pembelajaran PBL. 
Peningkatan aktivitas peserta didik dalam pembelajaran menjadikan knowledge peserta didik bertambah sehingga pada saat menyelesaikan perawatan mekanisme katup dan kelengkapannya, peserta didik dapat menerapkan tahapan-tahapan untuk melaksanakan perawatan mekanisme katup dan kelengkapannya dengan tepat. [14] mengemukakan bahwa dengan meningkatnya keterampilan berpikir kritis peserta didik, maka hasil belajarnya akan mengalami peningkatan. [17] dengan menggunakan model pembelajaran Problem Based Learning (PBL) dapat meningkatkan hasil belajar siswa.

\section{SIMPULAN}

Berdasarkan hasil penelitian yang telah dilaksanakan, peneliti dapat menarik simpulan bahwa diterapkannya model pembelajaran PBL pada kompetensi dasar perawatan mekanisme katup dan kelengkapannya, dapat meningkatkan keterampilan berpikir kritis dan hasil belajar peserta didik serta mencapai tujuan pembelajaran. Hal tersebut dapat dibuktikan dengan:

1. Penerapan model pembelajaran PBL dalam pembelajaran kompetensi dasar perawatan mekanisme katup dan kelengkapannya dalam dapat meningkatkan keterampilan berpikir kritis peserta didik dalam sebuah proses pembelajaran;

2. Dengan penerapan model pembelajaran PBL pada kompetensi dasar perawatan mekanisme katup dan kelengkapannya dapat meningkatkan hasil belajar peserta didik;

3. Peningkatan keterampilan berpikir kritis peserta didik meningkat sebesar 32,08\% setelah penerapan model pembelajaran PBL;

4. Peningkatan hasil belajar peserta didik sebesar $33,97 \%$ setelah penerapan model pembelajaran PBL. Dengan adanya peningkatan hasil belajar maka peserta didik yang mencapai nilai SKM sebanyak 53 peserta didik $(100 \%)$.

\section{DAFTAR PUSTAKA}

[1] A. Mukhadis, "Sosok manusia indonesia unggul dan berkarakter dalam bidang teknologi sebagai tuntutan hidup di era globalisasi," Jurnal Pendidikan Karakter, vol. 2, no. 2, 2013.

[2] M. Pavlova, Technology and vocational education for sustainable development: Empowering individuals for the future, vol. 10. Springer Science \& Business Media, 2008.

[3] M. Orey, Emerging perspectives on learning, teaching and technology. CreateSpace North Charleston, 2010.

[4] Kemdikbud, Model Pembelajaran Berbasis Masalah/PBL. Jakarta: Kementerian Pendidikan dan Kebudayaan Republik Indonesia, 2013.

[5] W. R. Yount and D. Odom, "Educational Psychology CEEF 9402," Cell, vol. 817, pp. 9381303, 2018.

[6] R. Paul and L. Elder, "Critical Thinking: Strategies for Improving Student Learning, Part II.," Journal of Developmental Education, vol. 32, no. 2, pp. 34-35, 2008.

[7] H. Rahmatika, S. R. Lestari, and M. S. Sari, "Preliminary study of PBL-based e-module development based on research results to improve students' critical thinking skills and cognitive learning outcomes," in AIP Conference Proceedings, 2021, vol. 2330, no. 1, p. 030046.

[8] N. A. Handoyono and Z. Arifin, "Pengaruh inquiry learning dan problem-based learning terhadap hasil belajar PKKR ditinjau dari motivasi belajar," Jurnal Pendidikan Vokasi, vol. 6, no. 1, pp. 31-42, 2016.

[9] D. Y. Nainggolan, "Penerapan Model Problem Based Learning ( $\mathrm{Pbl}$ ) Untuk Meningkatkan Kemampuan Berpikir Kritis Siswa Berbantuan Aplikasi Math Mobile Learning," CARTESIUS: Jurnal Pendidikan Matematika, vol. 3, no. 1, pp. 87-100, 2020.

[10]T. Pramono and S. Astuti, "Implementation of Problem Based Learning (Pbl) To Improve Critical Thinking Ability And Mathematics Learning Outcomes," JURNAL PAJAR (Pendidikan dan Pengajaran), vol. 4, no. 2, pp. 464-471.

[11]C. E. Reinsini, I. W. Susila, and M. Cholik, "Application of Problem-Based Learning to Enhance Students Learning Outcomes in Basic Competencies of Maintaining Brake Systems," International Journal for Educational and Vocational Studies, vol. 3, no. 2, pp. 139-145, 2021.

[12]U. SUSWATI, "Penerapan Problem Based Learning (Pbl) Meningkatkan Hasil Belajar Kimia," TEACHING: Jurnal Inovasi Keguruan dan Ilmu Pendidikan, vol. 1, no. 3, pp. 127-136, 2021.

[13]F. Fakhriyah, "Application of Problem Based Learning in Developing Students' Critical Thinking Ability," Journal of Indonesian Science Education, vol. 3, no. 1, pp. 95-101, 2014.

[14]D. Pamungkas, M. Mawardi, and S. Astuti, "Peningkatan Keterampilan Berpikir Kritis dan Hasil Belajar Matematika Pada Siswa Kelas 4 Melalui Penerapan Model Problem Based 
Learning," Jurnal Ilmiah Sekolah Dasar, vol. 3, no. 2, pp. 212-219, 2019.

[15]R. D. Desriyanti and L. Lazulva, "Penerapan Problem Based Learning Pada Pembelajaran Konsep Hidrolisi Garam Untuk Meningkatkan Hasil Belajar Siswa," JTK (Jurnal Tadris Kimiya), vol. 1, no. 2, pp. 7078, 2016.

[16]S. Aminah, H. Hambali, and N. Nurdiyanti, "Pengaruh Model Problem Based Learning Berbasis Online Terhadap Hasil Belajar Siswa Pada Konsep Virus," Jurnal Riset Dan Inovasi Pembelajaran, vol. 1, no. 2, pp. 220 227, 2021.

[17]Y. Y. Kusuma, "Peningkatan Hasil Belajar SIswa dengan Menggunakan Model Pembelajaran Problem Based Learning di Sekolah Dasar," Jurnal Basicedu, vol. 4, no. 4, pp. 1460-1467, 2020. 